\title{
Transform faults and large horizontal displacements of the ocean floor
}

\author{
G. RaNALLI $\left(^{*}\right)$ \\ Ricevuto il 9 Settembre 1968
}

\begin{abstract}
SUMmanY. - The evidence concerning the existence of transform faults and the occurrence of sea-floor spreading is reviewed and discussed. Available fault-plane solutions indicate that the direction of motion along some oceanic fracture zones is opposite to that which would be expected in case of transcurrent faults. The support for the sea-floor spreading liypothesis comes mainly from magnetic investigations. The problem, however, presents formidable dynamic and rheological aspects, and is far from being completely solved.
\end{abstract}

Riassunto. - I dati riguardanti l'esistenza di una nuova classe di faglie ("transform faults") e di grandi movimenti orizzontali del fondo marino ("sea-floor spreading") sono passati in rassegna e discussi. Studi dei meccanismi sismici all'ipocentro finora eseguiti indicano che il senso di movimento lungo alcune zone di frattura oceaniche è opposto a quello che ha luogo nel caso di faglie "classiche" a scorrimento orizzontale. Le anomalie magnetiche sembrano indicare l'esistenza di grandi spostamenti tangenziali del fondo marino. Il problema nel suo complesso, tuttavia, è lungi dall'essere risolto: parecchi aspetti dinamici e reologici sono ancora oscuri, e qualsiasi decisa conclusione sembra essere prematura.

\section{INTRODUCTION.}

The aim of this paper is to review the known mechanical evidence of the existence of transform faults of the ridge-ridge type, to examine the correlations between transform faulting and assumed movements of the ocean floor, and to discuss some of the implica-

(*) University of Illinois, Urbana, Illinois. 
tions of transform faulting and sea-floor motion from a generalized geodynamic viewpoint.

The morphotectonic units taken into consideration are mid-ocean ridges and fracture zones. Mid-ocean ridges are present in the central portions of the Atlantic, Arctic, Indian, and Pacific oceans. A rift valley lying along the axis of the ridge has been found in many places, and it has been proposed ( $\left.{ }^{1}\right)$ that such a rift represents a continuous pattern associated with a world-encircling mid-ocean morphotectonic belt. This postulated continuity is essentially based on seismic evidence, since the rift valley, where detected, has been found to coincide with the belt of mid-oceanic earthquake epicenters. But in many places the topography of the bottom shows no trace of a median valley $\left(^{2}\right)$. The flanks of mid-ocean ridges show more or less rugged topography, and descend to the ocean-basin depth on both sides of the crestal zone. All major topographic features are considered to be roughly parallel to the axis of the ridge, but this is not always the case and sometimes no topographic linearity is present $\left(^{3}\right)$. All earthquakes occurring along the crestal zone are classified as shallow (focal depth less than $60 \mathrm{~km}$ ) by Gutenberg and Richter $\left({ }^{4}\right)$, and large shocks are rare. Midocean ridges are currently believed to be the result of tension perpendicular to their strike $\left.{ }^{5}\right)$. Such tension is ascribed either to the drag of upper-mantle convection currents, or to the expansion of the Earth. The ridges appear to be in isostatic equilibrium $\left({ }^{8}\right)$, and uppermantle seismic velocities beneath the crestal zone are unusually low $(7.2$ to $7.6 \mathrm{~km} / \mathrm{sec})$. The third layer appears to be thinner than usual $\left({ }^{7}\right)$.

Fracture zones are long bands of irregular topography that generally separate regions of different sea-floor depths $\left(^{8}\right)$. Many of them are known, mainly in the equatorial Atlantic and northeastern Pacific. In many cases, they apparently displace ridges and bands of magnetic anomalies. Fracture zones in the Atlantic have been described by Heezen, Bunce, Hersey and Tharp $\left({ }^{9}\right)$, and Heezen, Gerard, and Tharp $\left({ }^{10}\right)$. At first they were interpreted as sinistral transcurrent faults, since this is the direction of motion that can be inferred from the apparent displacement of different segments of the ridge; along the Chain fracture zone, for instance, the apparent of set is 180 miles. Fracture zones in the Pacific have been described by Menard ( $\left.{ }^{7}\right)$; they are thousands of miles long, and appear to end abruptly at the boundary of the continental masses.

Figure 1 shows the major tectonic features of the Earth, with special reference to the ocean floor. Dotted lines represent the topo- 

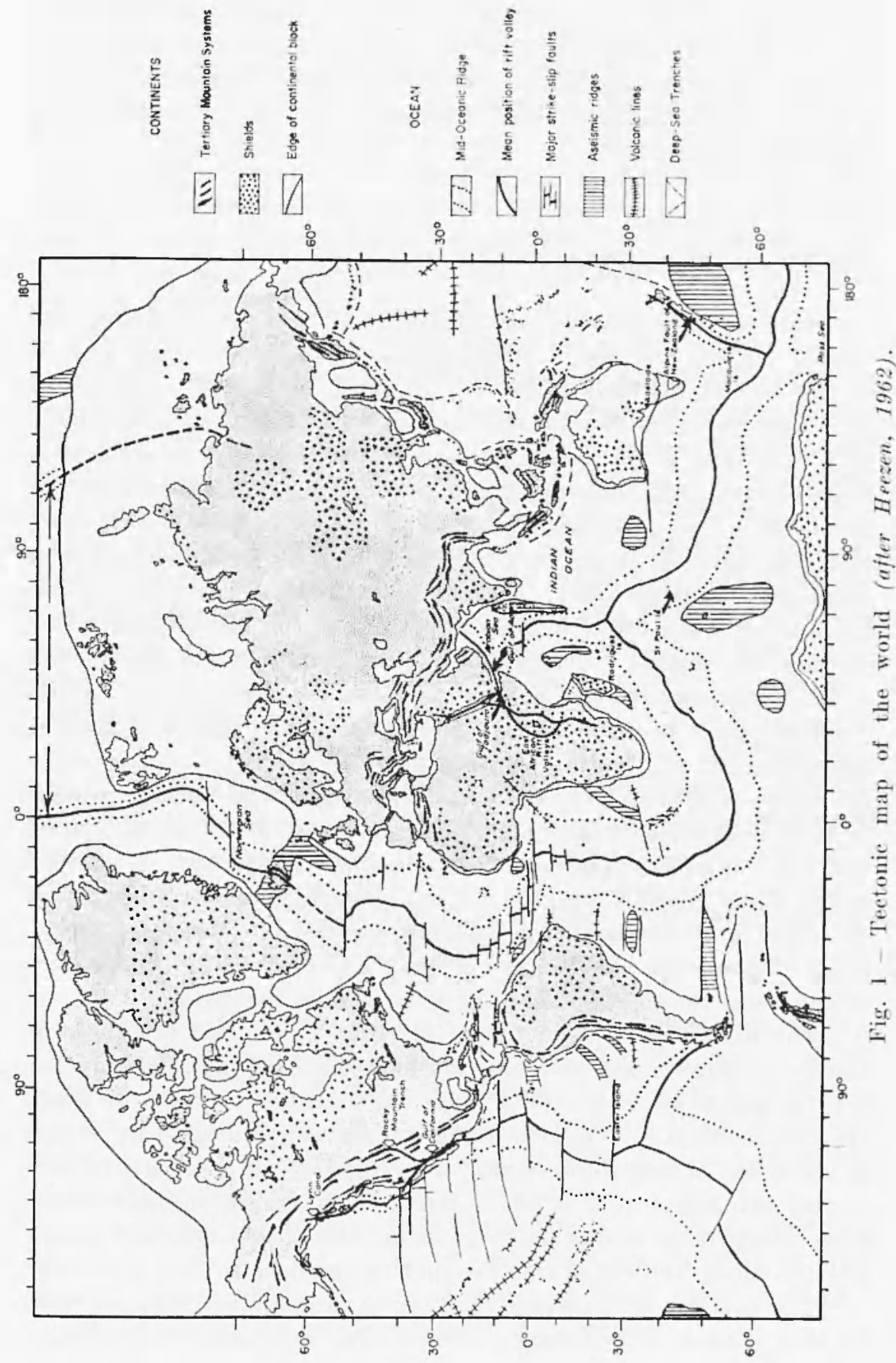
graphic boundaries of mid-ocean ridges (note that these boundaries are considered to be wider by other authors); continuous heavy lines represent the postulated position of the rift valley (they are essentially a plot of mid-oceanic earthquake epicenters); continuous thin lines represent fracture zones.

THE NOTION OF TRANSFORM FAULT.

The three classical types of faults (thrust, transcurrent, and normal faults), and their relations with the state of stress present in the crustal material subject to fracture, have been investigated by Anderson (11). Fanlts are regarded as shear fractures; accordingly, they will take place along planes that theoretically coincide with those of maximum shearing stress. The planes of maximum shearing stress bisect the angles made by the least and the greatest stress direction, but fracture, as shown also experimentally, occurs along planes which form an angle of $30^{\circ}-45^{\circ}$ with the direction of greatest pressure; the intermediate stress direction is parallel to the line of intersection of these two planes. Since the boundary conditions at the surface of the Earth require that no shearing stress be present at the surface, it follows that, near the surface and in not too rugged a landscape, the vertical is one of the principal stress directions, while the other two stress directions lie in the horizontal plane. This an be assumed to be at least statistically valid over large areas. Then the correlation between conjugate system of contemporary faults and orientation of the stress ellipsoid can be deduced. On this basis, Anderson has correlated each classical type of faulting with one particular orientation of the stress ellipsoid in a given area. It should be noted that, in any ase, the effect of faulting is to relieve the stress.

The existence of a new class of shear faults that involve large horizontal movements and end abruptly at both terminations has been proposed by Wilson $\left({ }^{12}\right)\left({ }^{13}\right)\left({ }^{14}\right)$. The faults of this class are called "transform faults". Oceanic fracture zones were indicated by Wilson as examples of transform faults of "ridge-ridge type", that is, connecting two segments of a ridge. A ridge-ridge transform fault terminates abruptly at mid-ocenn ridge segments at both ends, and seismic activity along the whole fracture zone is confined to this part only.

The concept of transform faulting is intimately connected with the idea of sea-floor spreading $\left({ }^{15}\right)\left({ }^{16}\right)\left({ }^{17}\right)$. The basic underlying assump- 
tion of this hypothesis is that large-scale thermal convection cells do operate in the mantle. Then, the sea-floor marks the top of these convection cells and slowly spreads from mid-ocean ridges, which are zones of divergence, to trenches, which are zones of convergence. Fracture zones were tentatively explained by Dietz $\left({ }^{16}\right)$ as shear's between regions of slow and fast creep. The idea of sea-floor spreading has an important bearing on the hypothesis of continental drift, inasmuch as continents are not regarded as sialic blocks " sailing " on the upper mantle (which is deemed to be physically impossible), but are supposed to move along with it.

The sea-floor spreading hypothesis implies that oceanic crust is being formed on the crest of the ridges, drifted laterally away on both sides, and then disappears downwards in trenches or under mountains $\left({ }^{18}\right)$. The material forming it is considered to be serpentinized peridotite, i.e., hydrated mantle material. This model is highly speculative, but can be regarded as a useful working hypothesis.

In Wilson's scheme $\left({ }^{12}\right)\left({ }^{13}\right)\left({ }^{14}\right)$, each segment of the ridge produces new crustal material. Transform faults, therefore, mark the boundary between region of opposite spreading directions, and should be moving and active seismically only along the line between the intercepts with two related segments of the ridge. Then two important consequences follow:

(a) the direction of motion along the fault plane in the case of transform faults is opposite to that occurring along transcurrent faults (see Figure 2);

(b) the offset of the two related segments of the ridge does not change during the faulting process.

Accordingly, the apparent offset between two ridge segments is deceiving; it is not caused by faulting at all, but it is merely a consequence of the shape of the original break in the crustal block that was subsequently rifted into two parts and drifted away by sea-floor spreading. This hypothesis is advanced by Wilson as an explanation of the fracture zones in the equatorial Atlantic.

It appears, therefore, that transform faults merely represent boundary zones between regions of opposite creep direction, and are possibly located along old lines of weakness. The cause of creep is currently thought to be mantle thermal convection. 
Wilson $\left({ }^{12}\right)\left({ }^{13}\right)\left({ }^{14}\right)$ has proposed various examples of transform faults: Wegener and Ie Geer faults in the Sorth Atlantic ridge termination; equatorial Atlantic fracture zones; San Andreas fault in

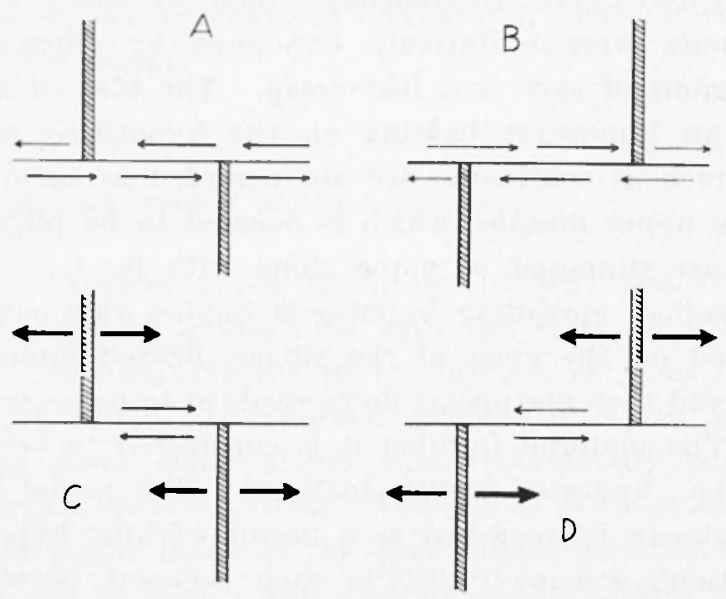

Fig. 2 - Direction of motion along the fault plane in case of $(A)$ sinistral 1.ranscurrent, (B) dextral transcurrent, (C) dextral transform, and (D) sinistral transform faults. Striped areas: crestal zones of the ridge; thin arrows: directions of motion; thick arrows: directions of sea-floor spreading.

California; Queen Charlotte Island fault off the coast of British Columbia; some Pacific fracture zones. In particular, the equatorial Atlantic fracture zones are dextral transform faults, and so is the San Andreas fault. Consequently, if this hypothesis yields a correct picture, the system ridge segments-fracture zones in the Atlantic reflects the shape of the initial break between Africa and South America and no relative motion of the ridge segments has occured; whereas the floor of the Pacific ocean is moving counterclockwise (northward) with respect to the Sorth American continental mass along the San Andreas and Queen Charlotte Island faults.

\section{RESTITS OF SEISAIC S'IUDLES.}

Information about the occurrence and nature of faulting can be obtained by accurate determination of the geographic location of seismic foci and by fault-plane studies. As stated above, mid-ocean epicenters coincide with the axis of a world-encircling mid-ocean 
ridge system. Oceanic fracture zones, in general, are seismically active only along their portion between the intercepts with the two ridge segments apparently cut by the fracture. On the other hand, the northeastern Pacific faults with E-W trend appear to be seismically inactive except a small segment of the Mendocino scarp extending about $240 \mathrm{~km}$ westward from the San Andreas fanlt (19); this fact seems to indicate that at present most of them are quiescent.
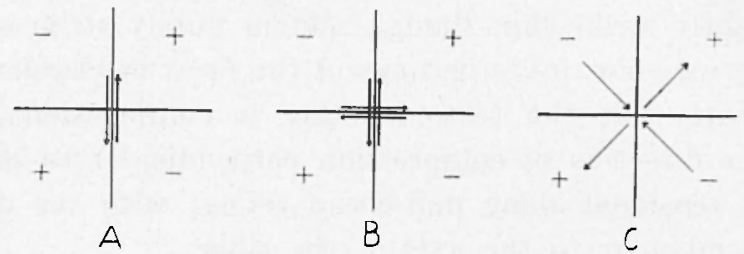

Fig. 3 - Earthquake focal models giving rise to a quadrant distribution of first motions: (A) single couple; (B) double couple; (C) pairs of forces.

The study of earthquake focal mechanism can give very useful information about the direction of motion at the focus. Various models have been devised in order to give a consistent picture of the phenomena taking place, and to explain the observed distribution of first motions. Such distributions are of several difterent types; the one which will be considered here is the quadrant distribution, since it is the most commonly observed in morphotectonic units such as midocean ridges and oceanic fracture zones. Figure 3 shows three equivalent models that produce the same $P$-wave distribution of first motions; a plus sign indicates compression, a minus sign indicates dilatation. Cases (A), (B), and (C) are idealized ones, inasmuch as the nodal planes are vertical, and therefore the nodal lines intersect at light angles. It is apparent that it is not possible to infer the system of forces and the mechanism by which they act at the focus from the observed distribution of $P$-wave first motions only. There is a tendency among current workers to discard model $(\mathrm{C})$, on the ground that earthquake mechanism should be similar to faulting. Then, a distinction between model (A) and (B) can be made by observing the $S$-wave distribution. This task is considerably more difficult than the detection of $P$-wave distribution. Theoretically, model (A) should show a two-lobe $S$-wave distribution pattern, and model (B) a fourlobe pattern $\left({ }^{20}\right)$. 
In particular areas with a dense network of seismic stations, the curvature of the Earth may be ignored. But, if data from distant stations are also used, some suitable projection (usually some kind of stereographic projection) must be used. An account of the various geometrical representations of fault-plane solutions has been given by Scheidegger $\left({ }^{21}\right)$. From fault-plane solutions data, Hodgson $\left({ }^{20}\right)\left({ }^{20}\right)$ has concluded that, at least in the range of $12-650 \mathrm{~km}$ focal depth, faulting in large earthquakes in most of the seismic areas of the world is predominantly strike-slip, though seldom purely strike-slip. From a global point of view, investigations of the focal mechanism of earthquakes indicate that the tectonic state is compressional in island arcs, with the direction of compression perpendicular to the strike of the arc, and tensional along mid-ocean ridges, with the direction of tension perpendicular to the axis of the ridge.

Sykes ${ }^{23}$ ) has investigated the mechanism of 17 earthquakes on mid-ocean ridges and their continental extensions (African rift system); ten of these earthquakes occurred on fracture zones intersecting the crest of the mid-ocean ridge. Most of them were in the Atlantic fracture zones, but some also in zones related to the East Pacific rise. The results can be summarized as follows:

(1) focal mechanisms appear to be of the double-couple type (24).

(2) earthquakes that are located on the mid-Atlantic ridge but not on fracture zones show a predominance of normal faulting; the inferred axes of maximum tension are approximately perpendicular to the axis of the ridge;

(3) seismic activity along fracture zones is concentrated almost exclusively along the portion between the two apparently displaced segments of the ridge;

(4) on fracture zones, the motion is of the strike-slip type on steeply dipping planes, and the strike of one of the two nodal planes is always very close to the strike of the zone; in every case, the inferred direction of displacement is opposite to that expected for transcurrent faults, and in complete agreement with that predicted for transform faults.

Therefore both the geographic distribution and the mechanism of earthquakes occurring on oceanic fracture zones confirm the existence of transform faults. Figure 4 gives the spatial distribution of some earthquake epicenters on the mid-Atlantic ridge and associated 
TRANSFORM FAULTS AND LARGE HORIZONTAL DISPLACEMENTS, ETC. 447

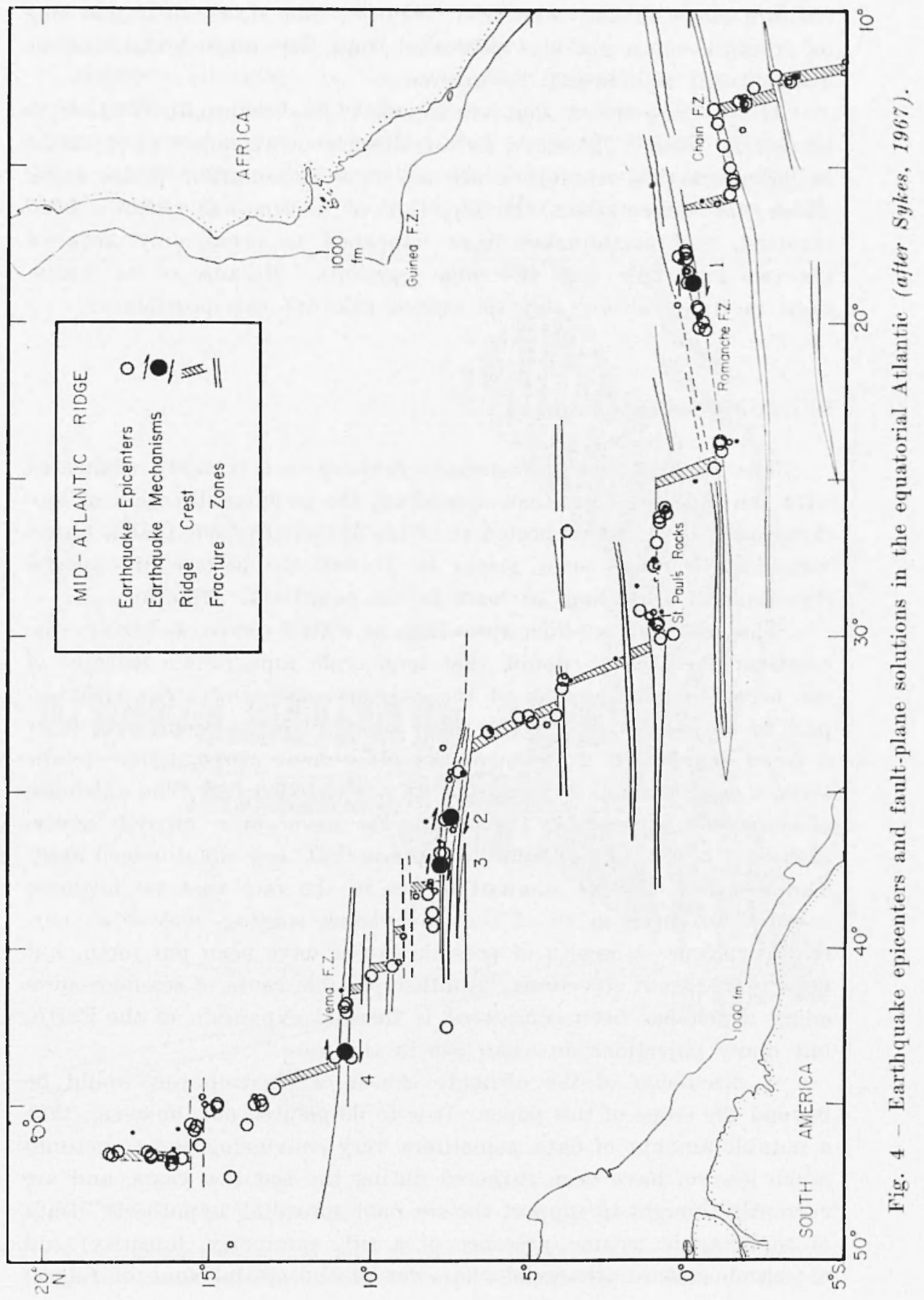


fracture zones in the equatorial Atlantic; four mechanism solutions on fracture zones are also presented, and the inferred direction of displacement is indicated by arrows.

It is to be noted that earthquakes give information which is limited in time. Therefore, as an alternative explanation, it might be proposed that fracture zones are true transcurrent faults along which, for some reason, the direction of motion has recently been reversed, and earthquakes have happened to occur only between the two intercepts with the ridge segments. Because of its limitations in time, seismic analysis camnot rule out this possibility.

\section{SFA-PLOOR SPREADTNG DATA.}

The phenomenon of transform faulting is intimately commected with the concept of sea-floor spreading; the peculiar direction of motion, opposite to that expected from the apparent ofiset, that is observed along fracture zones, seems to fit well the picture of opposite directions of spreading, at least in the equatorial Atlantic.

The notion of sea-floor spreading, as stated above, is highly speculative; there is no doubt that large-scale topographic features of the orean floor, expecially in the Atlantic, are symmetric with respect to the crestal zone of the ridge (or rift, when present) and show a trend parallel to it; but, on the other hand, topographic details show a large amount of deviation from such linearity. The existence of convection currents in the mantle has never been proved; nevertheless, it is not unreasonable to suppose that they could indeed exist. The weakness of this assumption lies in the fact that no ultimate account has been given of the phenomena causing convection currents to occur. A wealth of possible canses have been put forth, but none is free from objections. Another possible canse of sea-floor spreading which has been considered is thermal expansion of the Earth, but many objections do exist also in this case.

A discussion of the ultimate causes of diastrophism would be beyond the scope of this paper. It is to be pointed out, however, that a notable amomnt of data, sometimes very ronvincing and sometimes much less so, have been gathered during the last few years, and are currently thought to support the sea-floor spreading hypothesis. Data of topographic nature (presence of a rift, symmetry, linearity) and of seismic nature (tensional rharacter of the (restal zone of ridges) 
lave already been mentioned; other evidence is mainly altorded by magnetic, heat flow, and petro-sedimentary data.

Magnetic anomalies on the ocean floor present a very peculiar striped pattern. They generally do not show rorrelation with the topography, and appear to be displaced at known faults. Figure 5 shows positive magnetic anomalies (in black) in some areas of the Pacific ocean of the coast of Sorth America. Several authors have

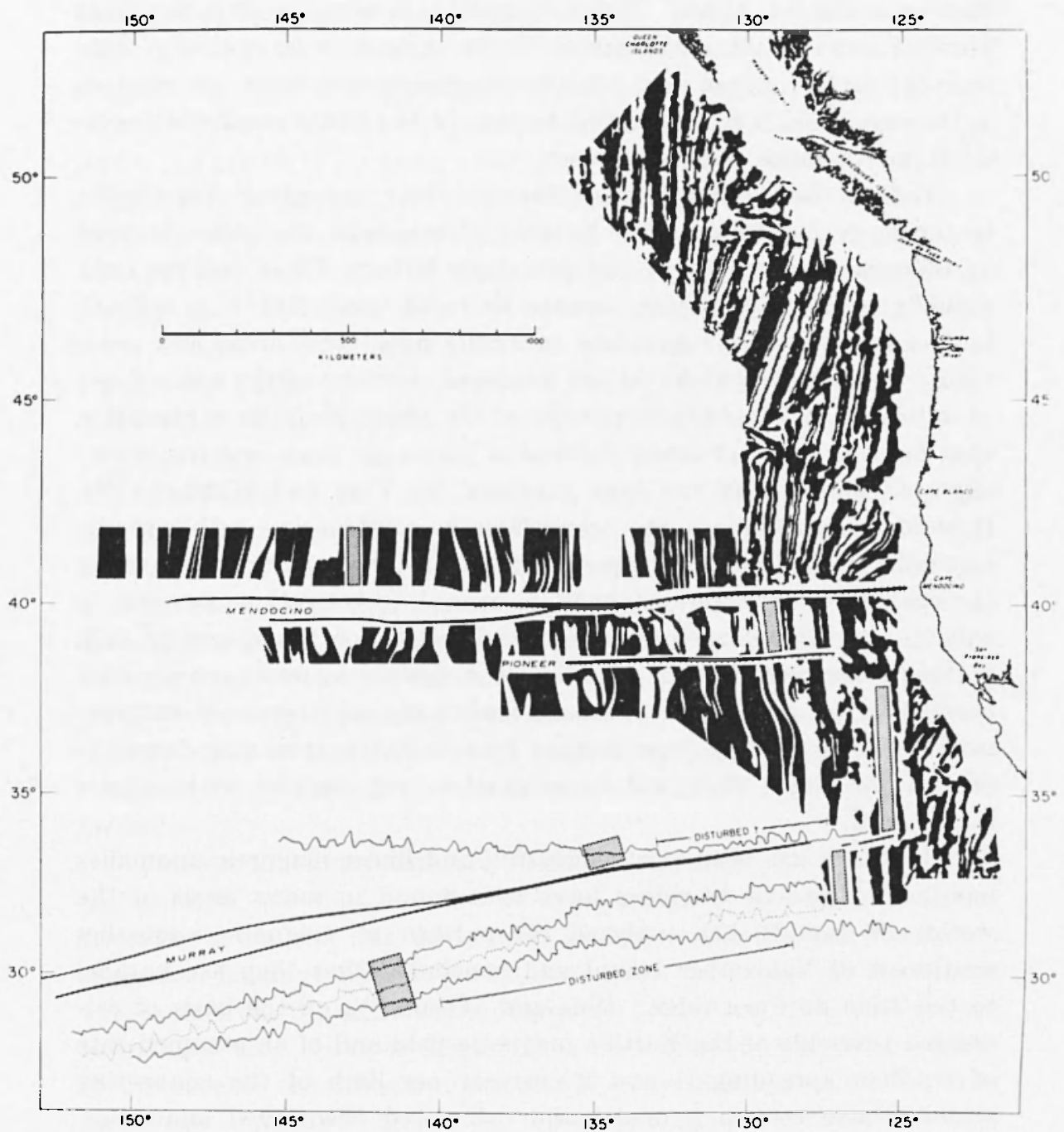

Fig 5 - Magnetic anomalies and offsets on fracture zones in the northeastern Pacific. Striped area: reference anomaly (after Menard, 196t). 
studied the region $\left({ }^{25}\right)\left({ }^{26}\right)\left({ }^{27}\right)$. In order to use magnetic anomalies for determining the presence of horizontal displacements and their amount, it must be assumed that the anomalies were originally continuous and predated the faults. Using this criterion, Hason and Raff $\left({ }^{25}\right)\left({ }^{26}\right)$ have stated that at the Murray fault a right-lateral displacement of about $155 \mathrm{~km}$ has taken place; Vacquier, Raff and Warren $\left({ }^{27}\right)$ have estimated that the total left lateral displacement across the Mendocino and Pioneer faults is $1420 \mathrm{~km}$. If this correlation is accurate, then the great fracture zones of the northeastern Pacific appear to be ordinary transcurrent faults, unless new crust-forming segments exist (or existed) in the region, with strike parallel to that of the linear magnetic anomalies and opposite apparent offset.

Before the formulation of the sea-floor spreading hypothesis, tentative explanations of the pattern of magnetic anomalies focused on topographic, structural, and petrologic factors. These factors, individually or in combination, cannot be ruled out. But it is difficult to imagine the same conditions occurring over large areas and practically almost everywhere in the surveyed portions of the ocean floor, as indicated by the uniform pattern of the anomalies. An explanation that has the merit of being valid at a planetary scale and fits generally well observation has been proposed by Vine and Matthews (28). It assumes spreading of the ocean floor in combination with periodic reversals of the Earth's magnetic field. If the main crustal layer of the oceanic crust is formed over an ascending convective current, it will be magnetized according to the direction of the magnetic field at the time; therefore the pattern of magnetic anomalies represents parallel strips of material alternately normally and reversely magnetized; since these strips were formed by symmetric spreading from the axis of the ridge, they will be symmetric and parallel with respect to the axis.

This idea has been very successful, and linear magnetic anomalies parallel to the axis of ridges have been found in many areas of the world. Wilson $\left({ }^{13}\right)$ has analyzed the pattern of magnetic anomalies southwest of Vancouver Island and concluded that they are parallel to the Juan de Fuca ridge. Vine and Wilson ${ }^{29}$, on the basis of calculated reversals of the Earth's magnetic field and of an assumed rate of sea-floor spreading (1 and $2 \mathrm{~cm} /$ year per limb of the convecting system) have set up a model and calculated theoretical anomalies. They found that the model shows a fairly good agreement with the observed magnetic profiles across the Juan de Fuca ridge. It is to 
be noted, however, that the spreading rate is not likely to remain constant during the whole life of a ridge. Vine $\left({ }^{30}\right)$ has found that; the observed anomalies over Reykjanes ridge, southwest of lceland in the Atlantic ocean, fit fairly well a model calculated from geomagnetic polarity epochs; the rate of spreading (per limb) in less than $1 \mathrm{~cm} /$ year. The same model applies also to the Carlsberg ridge in the Indian ocean, the mid-Atlantic ridge in the southern Atlantic, and in some portions of the east Pacific rise. Phillips $\left({ }^{31}\right)$ has concluded that magnetic protiles over the mid-Atlantic ridge near $27^{\circ}$ North support the Vine and Matthews hypothesis. The spreading rate appears to have been $1.25 \mathrm{~cm} / \mathrm{year}$ during the last 6 million years. Van Andel and Bowin $\left({ }^{3}\right)$ lave concluded that, over the mid-Atlantic ridge between $22^{\circ}$ and $23^{\circ}$ North, the agreement of the observed anomalies with the calculated anomalies (assuming a spreading rate of $1.4 \mathrm{~cm} / \mathrm{year}$ ) is moderately good. Magnetic anomaly patterns supporting the hypothesis of sea-floor spreading have also been found very recently by Pitman, Herron and Heirtzler $\left({ }^{32}\right)$ in the south Pacific, by Dickson, Pitman and Heirtzler ${ }^{(33)}$ in the south Atlantic, and by Le Pichon and Heirtzler ${ }^{34}$ ) in the Indian ocean.

Heat-flow data generally show anomalously high values over mid-ocean ridges. As compared to a world average of $1.5 \mu \mathrm{cal} / \mathrm{cm}^{2}$ sec, the crestal zone of the mid-Atlantic ridge between $30^{\circ}$ North and $40^{\circ}$ South has an average heat-flow value of $2.92 \mu \mathrm{cal} / \mathrm{cm}^{2} \mathrm{sec}$; the mid-Indian ocean ridge between $10^{\circ}$ North and $40^{\circ}$ South has an average value of $1.89 \mu \mathrm{cal} / \mathrm{cm}^{2} \mathrm{sec}$; and the East Pacific rise has an average value of $3.12 \mu \mathrm{cal} / \mathrm{cm}^{2}$ sec $\left({ }^{35}\right)$. These high values, coupled with the fact that seismic $P$-wave velocities in the upper mantle are slightly lower in the strip of high heat flow, might indicate a zone of weakness with ascending movements of partially melted (plastic) masses.

Petro-sedimentary data are of a more uncertain nature. Ewing $\left.{ }^{(36}\right)$ las pointed out that, on the average, sediment thickness increases gradually from the axis of a ridge (where sediments are sometimes altogether lacking) towards the flanks, and shows an abrupt increase at a distance from the axis varying from 100 to $400 \mathrm{~km}$. This would seem to indicate that sea-floor spreading is intermittent, with long periods of quiescence; the present cycle would have begun about 10 million years ago. Abrupt changes in sediment thickness, however, could also be caused by sudden variations in the rate of deposition. Van Andel and Bowin $\left({ }^{3}\right)$ have found metamorphosed basalts in the median 
valley of the mid-Atlantic ridge near $22^{\circ}$ North; on the basis of stratigraphic data, basement rock alteration, and thickness of manganese coating, they conclude that in the same area the crestal zone is Quaternary, while the upper flank is Miocene. Their tentative explanation is that long periods of tectonic tranquillity are present between spreading phases.

In conclusion, a wealth of data seem to give support to the seafloor spreading hypothesis; doubts, however, are not only present, but involve large and basic portions of the picture. Therefore the author feels that sea-floor spreading, at the present stage, should not be considered more than an useful and interesting working hypothesis. Fundamental rheological problems are still unsolved or not even taken into consideration.

\section{THE BASIC GEODYXAMC PROBLFM.}

Whenever a problem involving large movements in the upper part of the Earth is considered, two major difficulties are immediately apparent: the interpretation of data, and the search for causes. In the case of sea-floor spreading and associated fractures, the interpretation of data is still controversial and presents many manswered questions. It is clear that a meaningful search for the ultimate causes of diastrophism can be undertaken only when data have been properly interpreted. Mainly for this reason, the following observations are concerned, as far as possible, with aspects of the problem for which some data are available. The most speculative questions, however, cannot be completely avoided.

The expression "Earth's crust" will not be employed. If considerable horizontal displacements occur, and are transmitted rigidly or almost rigidly over large distances, they require a material with a strength much greater than that of the thin crust. Moreover, as stated above, if continental drift oc'urs, it camnot consist of the "sailing" of continental blocks on the underlying material, but the blocks must move along with the upper mantle, i.e., there must be a coupling between sea-floor spreading and continental drift, which alone might explain how such drift can take place. Therefore the tectonically active part of the Earth is not limited to the crust, but involves also the upper mantle, certainly the portion above the weak zone (asthenosphere), and possibly also portions below it, at least in an indirect 
sense. It is appropriate to call this active zone "tectonosphere".

It may be noted en passant that the problem of linding a process that can account for the relative motion of blocks of the tectonosphere and make it mechanically possible is formidable. This fact, by the way, is a strong argument in the hands of opponents of the continental drift hypothesis, and so far no satisfactory answer has been given to it.

Let us limit our attention to ocennic fracture zones, and consider in particular those in the equatorial Atlantic, where more information is available. Seismic evidence, regarding both the geographic distribution of epicenters and the direction of motion along the fractures, supports the conclusion that they are transform faults. But, because of the limitation in time of seismic analysis, the hypothesis that fracture zones are old transcurrent faults (that caused the ofiset of the ridge segments) along which in recent geological times the sense of motion has been reversed camnot be ruled out. This fact has already been pointed out above. It might be noted here that there is no direct reason to accept this hypothesis, but there is no direct reason to disrard it either.

Another problem arises when the focal depth of oceanic earthquakes is considered. Farthquakes occurring along fracture zones (and also along the crest of mid-ocean ridges) are known to be shallow. It has recently been calculated $\left({ }^{37}\right)$, on the basis of the slip rate deduced from magnetic studies, that the total seismic moment (proportional to the amplitude of seismic waves) along these transform faults can account for a zone of shearing only a few $\mathrm{km}$ thick $(1-6 \mathrm{~km})$. There are many assumptions in this procedure, since the rigidity must be assigned a priori and the time span is short; nevertheless, if the results are valid at least as order of magnitude, the shearing zone appears to be so shallow that it is very difficult to imagine how a creep that is supposed to have the power to raft continents can be so limited in depth.

Four lines of spreading have been recognized, namely in the Atlantic, Artic, Indian, and Pacific oceans, with dilterent rates of spreading but all active. It can be observed that continents appear to move away from the Atlantic, but encroach upon the sea-floor in the Pacific. The Pacific trenches are thought to be caused by downward motion of the sea-floor under advancing continents $\left({ }^{38}\right)$. The account of these phenomena by the sea-floor spreading hypothesis 
is unclear. Complex dynamic and rheological problems have been neglected. If only the continents have moved over some sort of "conveyor belt ", their direction of motion should be parallel to the great oceanic fracture zones. Considering again as an example the fracture zones in the equatorial Atlantic, it can be seen that they show a more or less parallel pattern with East-West trend. Morgan $\left({ }^{39}\right)$ explains this by assuming that the tectonosphere is divided into rigid blocks and observing that, on a spherical surface, the relative motion of one block with respect to another consists of a rotation; therefore a great fault that marks the boundary between two blocks must lie on a circle of latitude about the pole of relative rotation. All transform faults in the equatorial Atlantic seem to fit the same pole of rotation. But two questions arise here: first, if the relative motion of blocks interests the whole of the tectonosphere, it is strange that earthquakes along frarture zones (and also ridges) show such shallow foci; second, so far it has been impossible to find a satisfactory mechanism to arcount for the origin of these movements.

Finally, there is another point to be remarked. Implicit in the sea-floor spreading hypothesis is the concept that the offset between ridge segments apparently displaced by a fracture zone does not change or that, even if the relative position of the two segments changes with time, they were never together and therefore never formed a continuos ridge. If this is true (and it must be so if fracture zones are transform faults), it becomes very difficult to explain how these separate ridge crests, sometimes hundred of kilometers apart, developed; and if sea-floor spreading is caused by convection currents in the mantle, the pattern of these currents becomes very complicated and still more difficult to be accounted for. On the other hand, the hypothesis of expansion of the Earth seems to be ruled out by the implications that it would have over the force of gravity on the surface in past geological epochs.

The hard facts are that no hypothesis giving satisfactory explanation of all observed phenomena is available, and the phenomena themselves can be interpreted in different, sometimes opposite, fashions. The only possible (and provisional) conclusion is that the existence of a new class of faults, namely transform faults, has been established (within certain reasonable limits of doubt), and that geophysical and geological data regarding the ocean floor may be interpreted in terms of large horizontal displacements. But this is by no means a unique interpretation, and therefore no "explanation" of the 
tectonic deformation field has yet been found. It should be pointed out, however, that the very existence of transform faults implies to a certain extent the concept of sea-floor spreading. Thus, if the former is accepted and the latter rejected, one is left with an important unanswered question, since it is not clear how transform faults could occur if there were no sea-floor spreading. The difficulties contained in this problem, however, do not seem to be more formidable than those encountered when one tries to give a mechanically sound account for the motion of large blocks of the tectonosphere.

\section{ACKNOWLEDGMENT.}

The author is deeply indebted to Dr. A. F. Richards of the University of Illinois at Urbana for reading the manuscript and making suggestions for its improvement.

\section{REFE RENCES}

(1) HeEzen B. C., The deep-sea floor. "Continental Drift", pp. 235-288, ed. by S. K. Runcorn, Academic Press, New York, (1962).

(2) Shepard F. P., Submarine Geology. 2nd. ed., Harper \& Row, New York, (1963).

(3) Van ANDel T. H., Bowin C. O., MId-Atlantie ridge between 2:20 and $23^{\circ}$ North latitude and the tectonics of mid-ocean rises. "J. Geophys. Res.", 73, 1279-1298, (1968).

(4) Gutenherg B., Riciter C. F., Seismicity of the Earth and Associated Phenomena, 2nd ed., Princeton University Press, Princeton, New Jersey, (1954).

(5) Hewzen B. C., Ewing M., The mid-oceanic ridge, "The Sea ", pp. 388-410, ed. by M. N. Hill, vol. 3, Interseience, New York, (1963).

${ }^{6}{ }^{6}$ Worzes. J. I., Deep structure of coastal margins and mid-oceanic ridges. "Submarine Geology and Geophysics", pp. 335-359, ed. by W. F. Whittard and R. Bradshaw, Butterworths, London, (1965).

$\left({ }^{7}\right)$ Menard H. W., Marine Geology of the Pacific. MicGraw-Hill, New York, (1964).

( $\left.{ }^{8}\right)$ Heezen B. C., Menard H. W., Topography of the deep-sea floor, "The Sea", pp. 233-280, ed. by M. N. Hill, vol. 3, Interscience, New York, (1963).

(9) Heezex B. C., Bunce E. T., IIersey J. B., Tharp M., Chain and Romanche fracture zones. "Deep-Sea Research", 11, 11-33, (1964).

(10) Heezen B. C., Gerard R. D., Tharp I., The Vema fracture zone in the equatorial Atlantic. "J. Geophys. Res.", 69, 733.739, (1964). 
(11) Anderson E. M., The Dynamics of Faulting and Dyle Formation with Applications to Britain. 2nd ed. Oliver and Boyd, Edinburgh, (1951).

(12) Wilson J. T., A new class of faults and their bearing on continental drift. "Nature", 207, 343-347, (1965).

${ }^{\left({ }^{3}\right)}$ Wilson J. T., Transform faults, oceanic ridges, and magnetic anomalies southwest of Vancouver Island. "Science", 150, 482-485, (1965).

(1.1) WiLsox J. T., Submarine fracture zones, aseismic ridges and the International Council of Scientific Unions line: proposed western margin of the East Pacific ridge. "Nature", 207, 907-911, (1965).

(15) Dietz R. S., Continent and ocean basin evolution by spreading of the sea-floor. "Nature", 190, 854-857, (1961).

${ }^{(16)}$ DIETZ R. S., Ocean-basin evolution by sea-floor spreading. "Continental Drift" pp. 289-298, ed. by S. K. Runcorn, Academic Press, New York, (1962).

(17) II ess II. H., History of Ocean Basins Geol. Soc. Am., "Petrologic Studies ", pp. 599-620. A Volume to IIonor A.F. Buddington (1962).

${ }^{(18)}$ Hess Il. II., Mid-oceanic ridges and tectonics of the sea-floor. "Submarine Geology and Geophysics", pp. 317-332, ed. by W. F. Whittard and R. Bradshaw, Butterworths, London, (1965).

$\left({ }^{19}\right)$ BENIOFF II., Mlovements on major transcurrent faults. "Continental Drift ", pp. 103-134, ed. by S. K. Runcorn: Academic Press, New York, (1962).

${ }^{(20)}$ IIodgson J. H., Movements in the Earth's crust as indicated by earthquakes, "Continental Drift", pp. 67-102, ed. by S. K. Runcorn, Academic Press, New York, (1962).

(21) SCIIEIdegger A. E., The geometrical representation of fault-plane solutions of earthquakes. "Bull. Seism. Soc. Am.", 47, 89-110, (1957).

$\left({ }^{22}\right)$ IIOdgson J. II., Nature of faulting in large earthquales. "Bull. Geol. Soc. Am.", 68, pp. 611-644, (1957).

${ }^{(23)}$ Sykes L. R., Mechanism of earthquakes and nature of faulting on the mid-oceanic ridges. "J. Geophys. Res.", 72, pp. 2131-2153, (1967).

${ }^{(2 i)}$ Stauder W., Bollinger G. A., The S-wave project jor focal mechanism studies, earthquakes of 1963. "Bull. Seism. Soc. An.", 56, 1363-1371, (1966).

(25) Mason R. G., RafF A. D., Magnetic survey off the west coast of North America, $32^{\circ} \mathrm{N}$ latitude to $42^{\circ} \mathrm{N}$ latitude. "Bull. Geol. Soc. Am.", 72, 1259-1265, (1961).

${ }^{(26)}$ Rarr A. D., Mason R. G., Magnetic survey off the west coast of North America, $40^{\circ} \mathrm{N}$ latitude to $52^{\circ} \mathrm{N}$ latitude. "Bull. Geol. Soc. Am.", 72, 1267-1270, (1961).

${ }^{(27)}$ VACQUier V., RAFF A. D., WARren R. E., Horizontal displacements in the floor of the Northeastern Pacific ocean. "Bull. Geol. Soc. Am.", 72, 1251-1258, (1961).

$\left({ }^{28}\right)$ Vine F. J., Matthews D. H., Magnetic anomalies over oceanic ridges. "Nature", 199, 947-949, (1963). 
TRANSFORM FAULTS AND LARGE HORIZONTAL DISPIACEMENTS, ETC. 457

${ }^{(29)}$ Vine F. J., Wilsox J. T., Magnetic anomalies over a young oceanic ridge off Vancouver Island. "Science", 150, 485-489, (1965).

$\left({ }^{30}\right)$ Vine F. J., Spreading of the ocean floor: new evidence. "science ", 154. 1405-1415, (1966).

$\left({ }^{31}\right)$ Pinluips J. I., Magnetic anomalies over the Mid-Atlantic ridge near $27^{\circ} \mathrm{N}$. "Science", 157, 920-923, (1967).

$\left({ }^{32}\right)$ Pitsan W.C. III, Herron, E. M. Heirtzler J. R., Magnetic anom.alies in the Pacific and sea floor spreading. "J. Geophys. Res.", 73. 2069-2085, (1968).

${ }^{(33)}$ Dickson G. O., Pitman W. C. III, IIeirtzler J. R., Magnetic anomalies in the South Atlantic and ocean foor spreading. "1. Geophys. Res. ", 73, 2087-2100, (1968).

$\left({ }^{3.1}\right)$ Le Picion X., IIeirtzler J. R., Magnetic anomalies in the Indian ocean and sea-foor spreading. "J. Geophys. Res.", 73. 2101-2117. (1968).

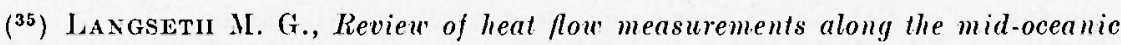
ridge system. "The World Rift System", pp. 349-363, Geol. Survey of Canada, Paper 66-14, Department of Mines and Technical Surveys, Ottawa, (1965).

${ }^{(36)}$ Ewing J., Ewisg MI., Sediment distribution of the mid-ocean ridges with respect to spreading of the sea-floor. "Science", 156, 1590-1592, (1967).

${ }^{(37)}$ BRUNe J. N., Seismic moment, seismicity, and rate of slip along major fault zones. "J. Geophys. Res.", 73, 777-784, (1968).

(38) Heirtzler J. R., Dickson G. O., Herron E. M., Pituax W. C. III, LE PICION X., Harine magnetic anomalies, geomagnetic field reversals, and motions of the ocean foor and continents. "J. Geophys Res.", 73, 2119-2136, (1968).

$\left.{ }^{(39}\right)$ MLoRgan W. J., Rises, trenches, great faults, and crustal blochs. "J. Geophys. Res.", 73, 1959-1982, (1968). 